
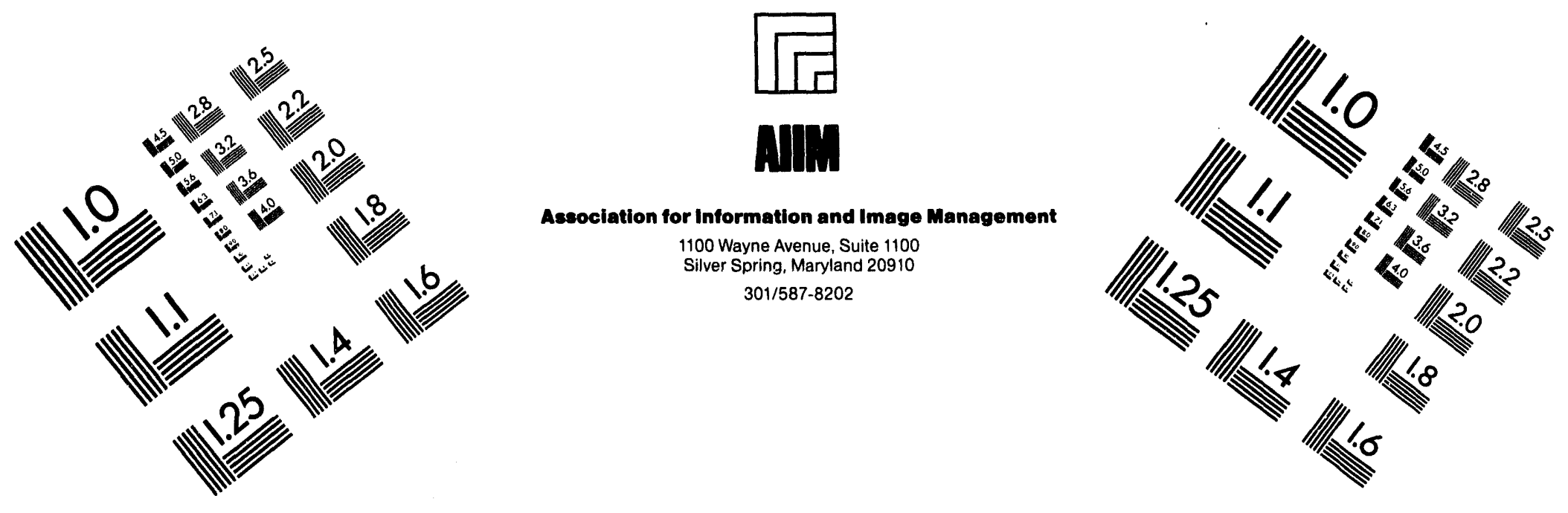

\title{
Centimeter
}

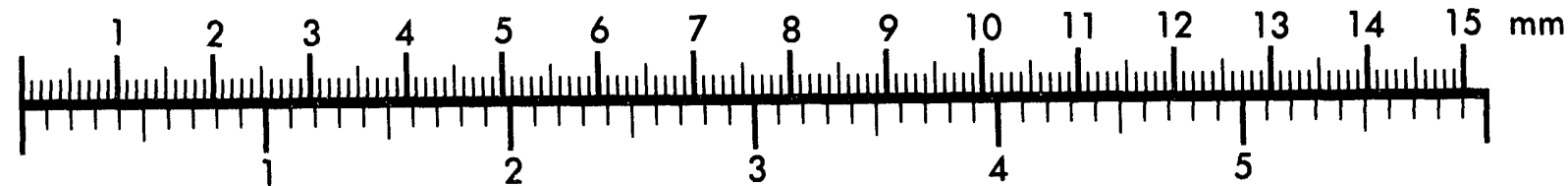
Inches
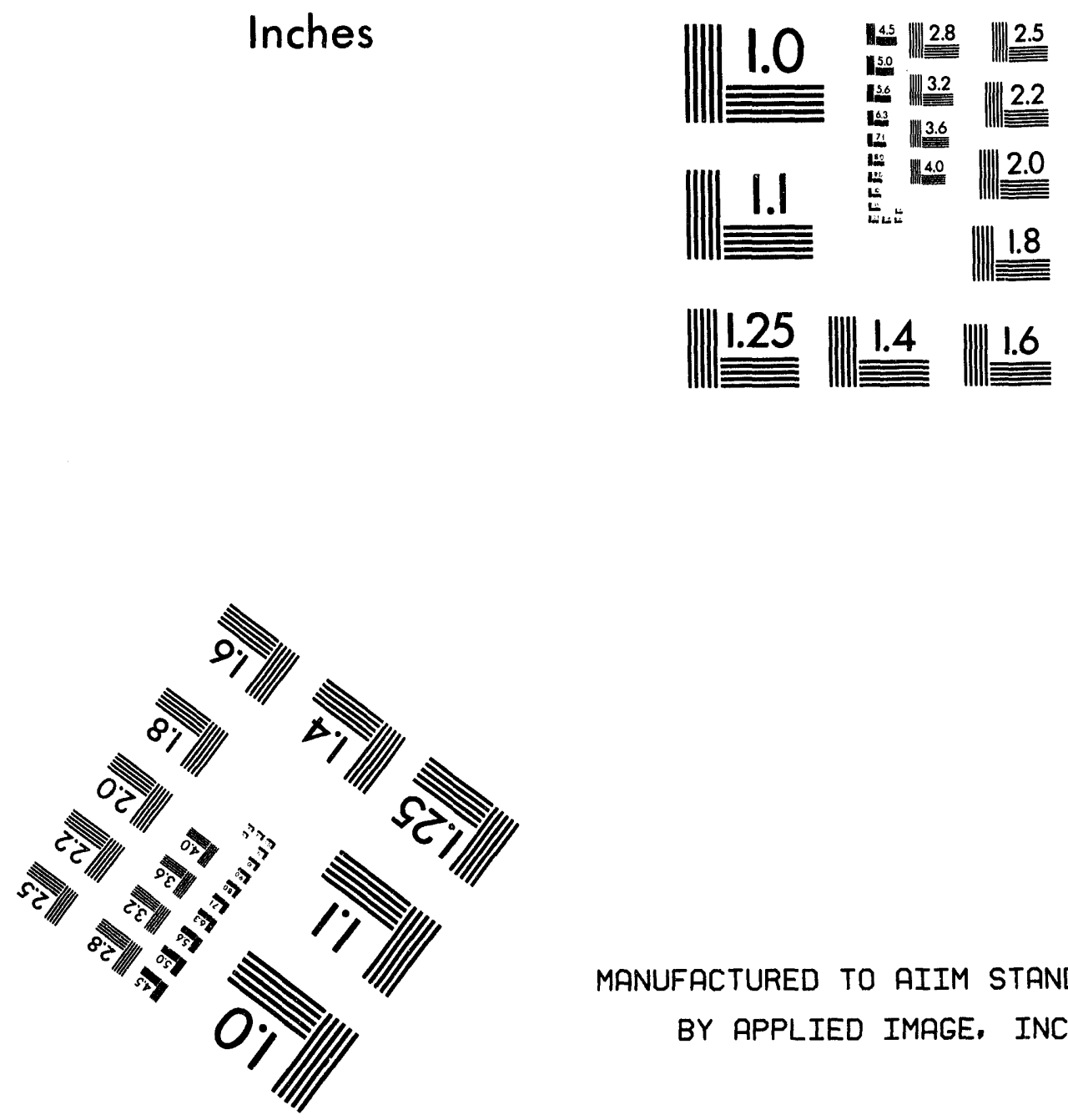

MANUFACTURED TO AIIM STANDARDS

BY APPLIED IMAGE, INC.

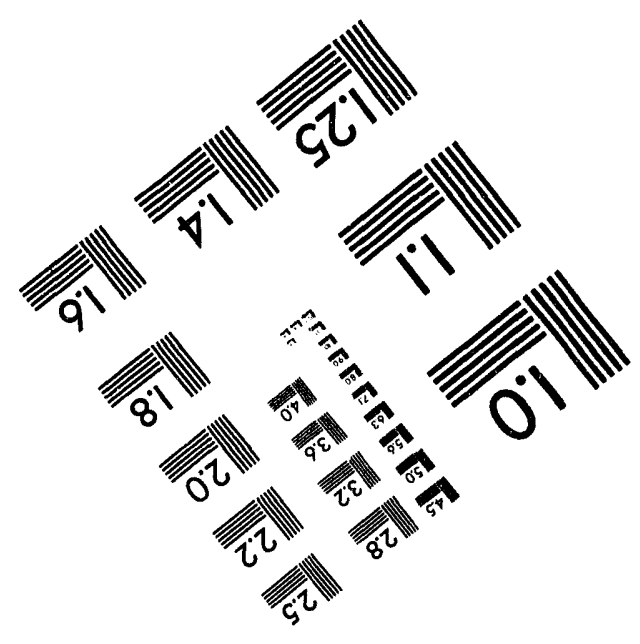



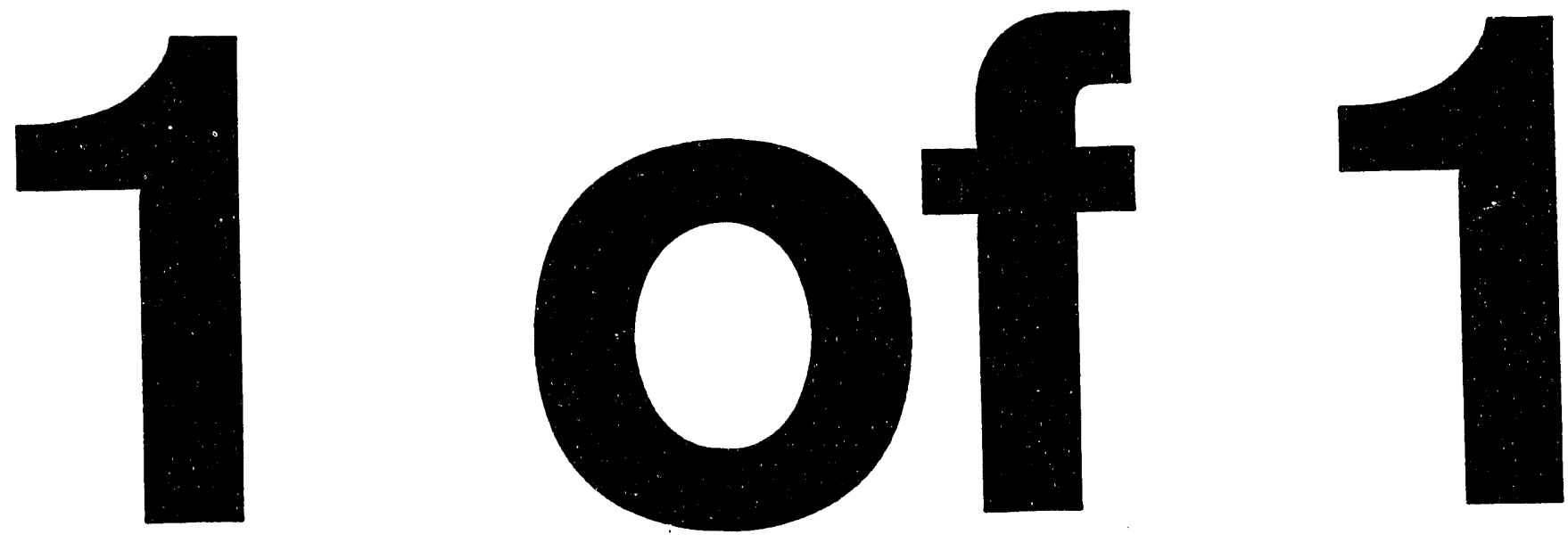
PNL-8993

UC-607

\section{Waste Tank Safety Program \\ Annual Status Report for FY 1993 \\ Task 5: Toxicology and Epidemiology}

D. D. Mahlum, Ph.D.

J. Y. Young, $\mathrm{CIH}$

September 1993

Prepared for Westinghouse Hanford Company

under a Related Services Agreement

with the U.S. Department of Energy

Contract DE-AC06-76RLO 1830

Pacific Northwest Laboratory

Richland, Washington 99352 


\section{Summary}

A toxicology team (D. D. Mahlum, task leader; J. Y. Young, associate task leader; and several others from within the Life Sciences Center) independently reviewed analytical data and provided advice concerning potential health effects associated with exposure to tank-vapor constituents at the Hanford site. Most of the emphasis was directed toward Tank 241-C-103, but a preliminary assessment was also made of the toxicologic implications of the cyanide levels in the headspace of Tank 241-C-108.

The objectives of this program are to 1) review procedures used for sampling vapors from various tanks, 2) identify constituents in tank-vapor samples that could be related to symptoms reported by waste-tank workers, 3) evaluate the toxicologic implications of those constituents by comparison to established toxicologic data bases, 4) provide advice for additional analytical efforts, and 5) support other activities as requested by the project manager and the cognizant Westinghouse Hanford Company Tank Vapor Issues Safety Resolution Manager.

A summary of the Pacific Northwest Laboratory (PNL) results is presented in Appendix A. In Appendix $B$, the geometric mean, the upper and lower confidence limits, and a best estimate of the true mean for Oregon Graduate Institute (OGI)/Sandia data have been calculated. Also listed are the available threshold limit values (TLVs) \{American Conference of Governmental Industrial Hygienists\}, recommended exposure limits (National Institute for Occupational Safety and Health (NIOSH)\}, permissible exposure limits (PELs), and short-term exposure limits (STELs) \{Occupational Safety and Health Administration (OSHA)\} along with a brief note of the health effects that have been noted with these compounds.

An unresolved issue is the actual concentrations of gases that workers are exposed to in their breathing zone. After better analytical data are available for headspace vapors, more consideration should be given to appropriate ways to sample outside of the tank.

Several needs still exist. The extant headspace-vapor data are the result of a single sampling episode, which does not allow determination of the variability of either the sampling procedure or changes in the concentrations of analytes in the tank over time. Also, it is not certain whether all compounds of toxicologic concern have been identified; it is possible that unidentified constituents are present that could contribute to health effects.

Uncertainty exists concerning potential interactions among components of the vapors. Many compounds cause symptoms similar to those reported by workers in the $\mathrm{C}$ farm. However, attempts to measure various compounds near the tanks shortly after reported exposures have not found levels of toxic compounds that would seem to account for the reported symptoms. Of course, the causative agent(s) might have dissipated before the ambient air could be analyzed. The uncertainties in accounting for all toxic materials in the vapors and the potential interaction among constituents may best be addressed by performing some biological characterization of the vapors. 


\section{Contents}

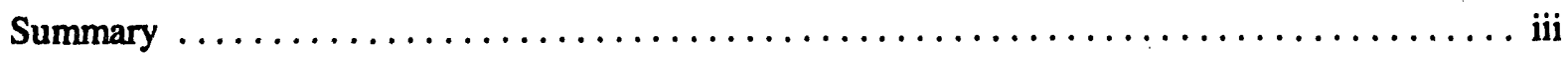

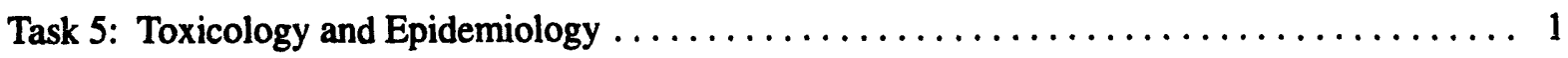

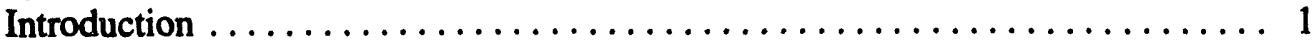

Background and Description of Tank $241-\mathrm{C}-103 \ldots \ldots \ldots \ldots \ldots \ldots \ldots \ldots$

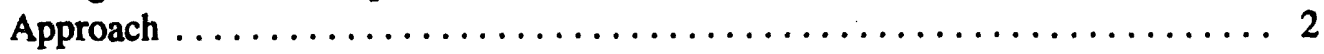

Unresolved Issues and Recommendations $\ldots \ldots \ldots \ldots \ldots \ldots \ldots \ldots \ldots$

Appendix A - Summary of Analyses of Headspace Constituents of

Tank $241-\mathrm{C}-103$ by Pacific Northwest Laboratory $\ldots \ldots \ldots \ldots \ldots \ldots \ldots$ A.1

Appendix B - Evaluation of Sandia/Oregon Graduate Institute Report

on Vapors from Tank $241-\mathrm{C}-103 \ldots \ldots \ldots \ldots \ldots \ldots \ldots \ldots \ldots \ldots \ldots \ldots \ldots \ldots \ldots \ldots$ 


\section{Waste Tank Safety Program \\ Annual Status Report for FY 1993 \\ Task 5: Toxicology and Epidemiology}

\section{Introduction}

A number of people have reported ill effects, including headaches, a burning sensation in the nose and throat, nausea, and impaired pulmonary function while working around waste tanks on the Hanford project. Pacific Northwest Laboratory (PNL)(a) was requested by Westinghouse Hanford Company (WHC) to assemble a toxicology team to independently review analytical data and provide advice concerning potential health effects associated with exposure to tank-vapor constituents. Dr. D. D. Mahlum was designated as the task leader and Mr. J. Y. Young as the associate task leader for this task. Several persons from within the Life Sciences Center, PNL, were designated as team members. These latter individuals possess expertise in general toxicology, analytical chemistry, cellular biology, pathology, regulatory toxicology, and developmental toxicology.

The objectives of this program are to 1) review procedures used for sampling vapors from various tanks, 2) identify constituents in tank-vapor samples that could be related to symptoms reported by waste-tank workers, 3) evaluate the toxicologic implications of those constituents by comparison to established toxicologic data bases, 4) provide advice for additional analytical efforts, and 5) support other activities as requested by the project manager and the cognizant WHC Tank Vapor Issues Safety Resolution Manager.

This effort was first funded during the first week of June, 1993. Because of the limited time available after funding, most of the emphasis has been directed toward Tank 241-C-103 (Tank C-103). This tank has been implicated in several reported exposures and is considered to contain a relatively complex set of vapor constituents. A preliminary assessment has also been made of the toxicologic implications of the cyanide levels in the headspace of Tank 241-C-108.

\section{Background and Description of Tank 241-C-103}

As indicated in the 1993 Program Plan for the Resolution of Tank Vapor Issues, WHC-EP-0562, musty and foul odors, including the smell of ammonia, have been reported to emanate from several single-shelled tanks. During the period between July 1987 and May 1992, 16 complaints of exposures to cdors involving 27 workers were reported. Ten of these occurrences, involving 18 workers, were linked to C Tank Farm. In particular, Tank C-103 was implicated with six of the reported occurrences with 12 workers sustaining lost time.

Tank C-103 was constructed about 1943 to 1544 (Hanlon 1991). It is one of twelve 530,000-gal tanks in the C Tank Farm located in the 200 East area. It consists of a carbon-steel liner with a reinforced concrete shell (Anderson 1990).

(a) Pacific Northwest Laboratory is operated for the U.S. Department of Energy by Battelle Memorial Institute under Contract DE-AC06-76RLO 1830. 
For a period of 33 years (1946 to 1979), Tank C-103 received about 30 types of waste from various sources, both directly and as a receiving tank in a tank cascade(a). According to Jungfleisch, the wastes added to Tank C-103 included wastes generated from four primary recovery processes, two secondary recovery processes, evaporators, in-tank solidification processes, semiworks operations, decontamination operations, nuclear $(\mathrm{N})$ reactor operations, PNLoperations, and both in-process and in-tank waste scavenging. Tank C-103 was also an accumulator tank for metal waste from other tanks before processing for uranium recovery and for supernatants from other tanks before processing for cesium recovery. In the September 22, 1988, memo of Carothers, it was noted that knowledge of the exact composition of the various materials added to Tank C-103 from decontamination wastes, $\mathrm{N}$ reactor waste, and PNL waste was lacking because of the then proprietary nature of those operations. However, it is likely that the tank contains tributyl phosphate (TBP), normal paraffin hydrocarbons (NPH), and various radiation-induced degradation products. After July 1979, no wastes were transferred into or out of Tank C-103. At present, Tank C-103 is designated as an organic tank and is on the Watch List (Strachan et al. 1993). In 1991, Hanlon estimated that the tank contained 62,000 gal of sludge and 133,000 gal of supernatant liquids. Various estimates have been made of the depth of the organic layer, but it probably lies between 10 and 13 in. If so, the organic layer would contain between 27,000 and $36,000 \mathrm{gal}$.

\section{Approach}

The task was approached in the following way: 1) descrif ave material about the tank farms, especially C farm, was reviewed; 2) meetings were held with WHC staff and others who had responsibility for tank vapor safety or who had participated in planning or in vapor sampling/analysis; 3 ) available analytical data for Tank C-103 were examined; 4) levels of constituents were compared with various guidelines used to regulate exposures to those materials; and 5) a recommended list of analytes was created from which the analytical chemists could develop validated methods for the next round of samples to be obtained from Tank C-103. Major responsibility for the initial efforts in this task has been assumed by the task leader and the associate task leader, although meetings have been held with various team members to brief them and to solicit their informal opinions.

Headspace samples had been obtained from Tank C-103 in September 1989 using a cryogenic sampling system. It should be noted that this system has not been validated, and therefore the samples obtained using it should only be considered as preliminary. Nonetheless, this set of samples represented the major ones available for detailed analyses; thus, the analyses from this set of samples served as the primary data source for this preliminary toxicologic evaluation. The analyses on these samples were performed by PNL. In addition to these samples, another set was obtained downstream from the high-efficiency particulate air (HEPA) exhaust filter using the SUMMATM canister technique in 1992. The information from the analyses of these samples by the Oregon Graduate Institute (OGI) was used in a qualitative way to confirm the presence of several of the chemicals identified by PNL in the headspace. The data for the headspace samples are reported in a February 1992 memo from Kirch to Dunbar, while the OGI results may be found in a draft report prepared by Einfeld, Rasmussen, and Bustard(b). Various other samples have also been taken from Tank C-103. These include 1) headspace vapor-trap samples taken September 1987, 2) headspace samples taken July 1988,

(a) F. M. Jungfleisch. October 2, 1987. Letter to K.G. Carothers - subject: Historical Perspectives of Wastes in Tank 241-C-103; and K. G. Carothers. September 22, 1988. Letter - subject: Tank 103-C Transaction History - Post January 1976.

(b) Interim Report on Hanford Tank C-103 Headspace Vapor Analysis: Cannister Sampling Results, September 1992. 
3) exhauster samples taken October 1989, 4) cryogenic and volatile organic samples in October 1989, and 5) cryogenic and charcoal-tube samples from the headspace in March 1991. In general, the analyses from these samples lend qualitative support for the presence of the substances reported from the 1989 cryogenic samples, although substantial quantitative differences exist.

As expected, the concentrations of constituents in samples taken directly from the headspace of Tank C-103 are higher than the concentrations found in the SUMMATM cannister samples taken outside of the tank downstream from the HEPA filter. However, both sets of samples agree that 1-butanol, acetone, acetic acid, NPHs with their alcohol and ketone derivatives, aromatic hydrocarbons, and several chlorinated hydrocarbons were present. In addition, the PNL data indicate significant concentrations of ammonia, TBP, and nitrogen oxides in the headspace vapor. The PNL analyses had the advantage of having more material present, which aided in identifying constituents found in lower concentrations as well as allowing analyses to generally be performed well above detection limits. On the other hand, the OGI/Sandia chemists had multiple SUMMATM canisters available so that variability could be determined.

A summary of the PNL results is presented in Appendix A. In Appendix B, we have calculated the geometric mean, the upper and lower confidence limits, and a best estimate of the true mean for OGL/Sandia data. Also listed are the available threshold limit values (TLVs) (American Conference of Governmental Industrial Hygienists\}, recommended exposure limits (National Institute for Occupational Safety and Health (NIOSH)\}, permissible exposure limits (PELs) and short-term exposure limits (STELs) \{Occupational Safety and Health Administration (OSHA)\}, along with a brief note of the health effects that have been noted with these compounds.

We were requested by WHC and Northwest Instrument Systems, Inc. (NISI) to prepare a list of analytes that chemists at OGI/Sandia, Oak Ridge National Laboratory (ORNL), and PNL could use to establish validated methods for quantitative analysis of headspace vapors for Tank C-103. This list was to be considered preliminary to permit the chemist to prepare for Phase One of the tank sampling. A request was also made for recommendations for the levels at which the laboratories should be able to analyze the compounds. The constituents reported by PNL and OGI/Sandia were reviewed by the principal and associate investigators for their potential toxicologic importance. A list of analytes was prepared based on 1) concentrations reported by PNL and OGI/Sandia, 2) toxicity of the compounds (especially if potential carcinogenic activity was reported for a compound), and 3 ) the need to solidify the data on potential classes of compounds. For example, some evidence indicated the presence of nitriles, which could be of toxicologic importance. We therefore placed a nitrile (butyl nitrile) on the list to ensure that appropriate methods are validated so that confirmatory data could be obtained. The list and the limit of detection desired are given in Table 1. We wish to emphasize that this list is only temporary and intended for use in defining the quantitative methods to be employed in the next round of sampling for Tank C-103. Once the next sampling and analyses are performed, it is expected that the list will be modified to accommodate the new information. 
Table 1. Tentative List of Analytes for Tank C-103 and Possible Detection Limits for Validation Purposes

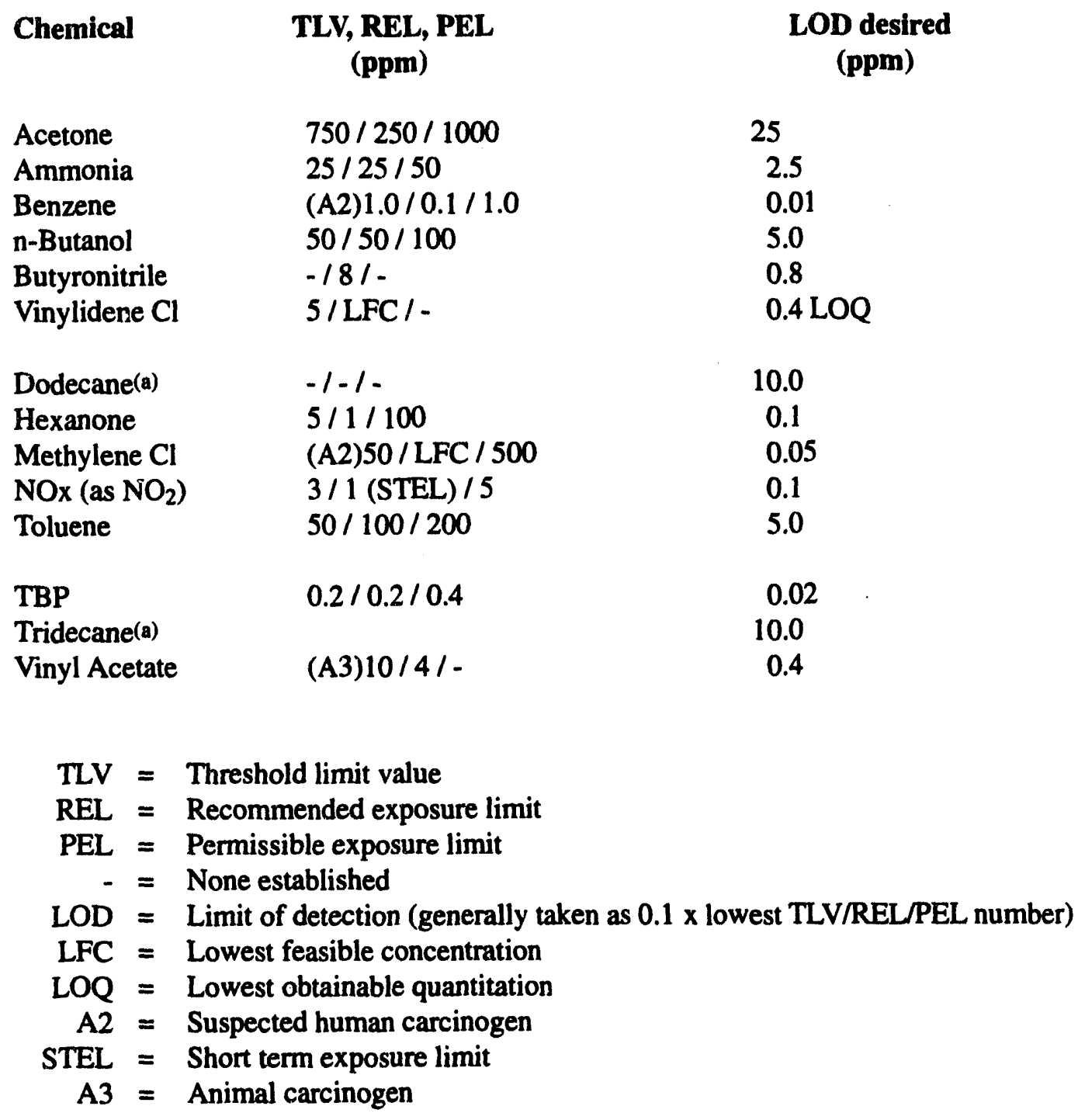

(a) No TLV, REL, or PEL values have been derived for dodecane or tridecane, so a value of $100 \mathrm{ppm}$ was arbitrarily selected as an average value based on RELs for pentane, hexane, heptane, octane, and nonane and a LOD calculated on the basis of 0.1 of that value.

\section{Unresolved Issues and Recommendations}

The PNL analytical data reviewed thus far have been the result of samples drawn directly from the headspace. Arguments have been raised that headspace concentrations do not reflect what workers might experience in their breathing zone. The magnitude of the breathing-zone exposure is influenced by the distance of the workers from the source and by meteorological conditions such as wind direction, wind velocity, humidity, temperature, and adiabatic gradients on the dispersion pattern of the vapors. The first step 
in understanding what worker exposures could be is to determine the chemicals and their concentrations in the headspace. Thus, headspace sampling should continue. However, as better analytical data for headspace vapors are developed, more consideration should be given to appropriate ways to sample outside of the tank.

The extant headspace vapor data are the result of a single sampling episode, which does not allow determination of the variability of either the sampling procedure or changes in the concentrations of analytes in the tank over time.

It is important that a series of samplings are performed to allow determination of both sampling and temporal variability.

It is not certain whether all compounds of toxicologic concern have been identified. Many peaks on gas chromatograms have not been identified, and it is possible that unidentified constituents exist that could contribute to health effects. Rigorous attempts to account for more of the mass, especially nitrogen and phosphorous compounds, are important.

Uncertainty also exists conceming potential interactions among components of the vapors. Many compounds cause symptoms similar to those reported by workers in the $\mathrm{C}$ farm. However, attempts to measure various compounds near the tanks shortly after reported exposures have not found levels of toxic compounds that would seem to account for the reported symptoms. Of course, the causative agent(s) might have dissipated before the ambient air could be analyzed. On the other hand, little information is available about interactions at the biological level between substances such as ammonia and NPH.

\section{References}

Anderson, J. D. 1990. A History of the 200 Area Tank Farms. WHC-MR-0132. Westinghouse Hanford Company, Richland, Washington.

Hanlon, B. M. 1991. Tank Farm Surveillance and Waste Status Report for June 1991. WHC-EP-0182-39. Westinghouse Hanford Company, Richland, Washington.

Strachan, D. M., W. W. Schulz, and D. A. Reynolds. 1993. Hanford Site Organic Waste Tanks: History, Waste Properties and Scientific Issues. PNL-8473. Pacific Northwest Laboratory Richland, Washington. 


\section{Appendix A}

Summary of Analyses of Headspace Constituents of Tank 241-C-103 by Pacific Northwest Laboratory 
Appendix A: Preliminary Evaluation c

Reported

Concentration $^{(a)}$
TLV', ppm

(American Conf. 1992-93:

Cook 1987)

8-h

TWA
Ceiling

STEL or Skin
Health.

\section{(}

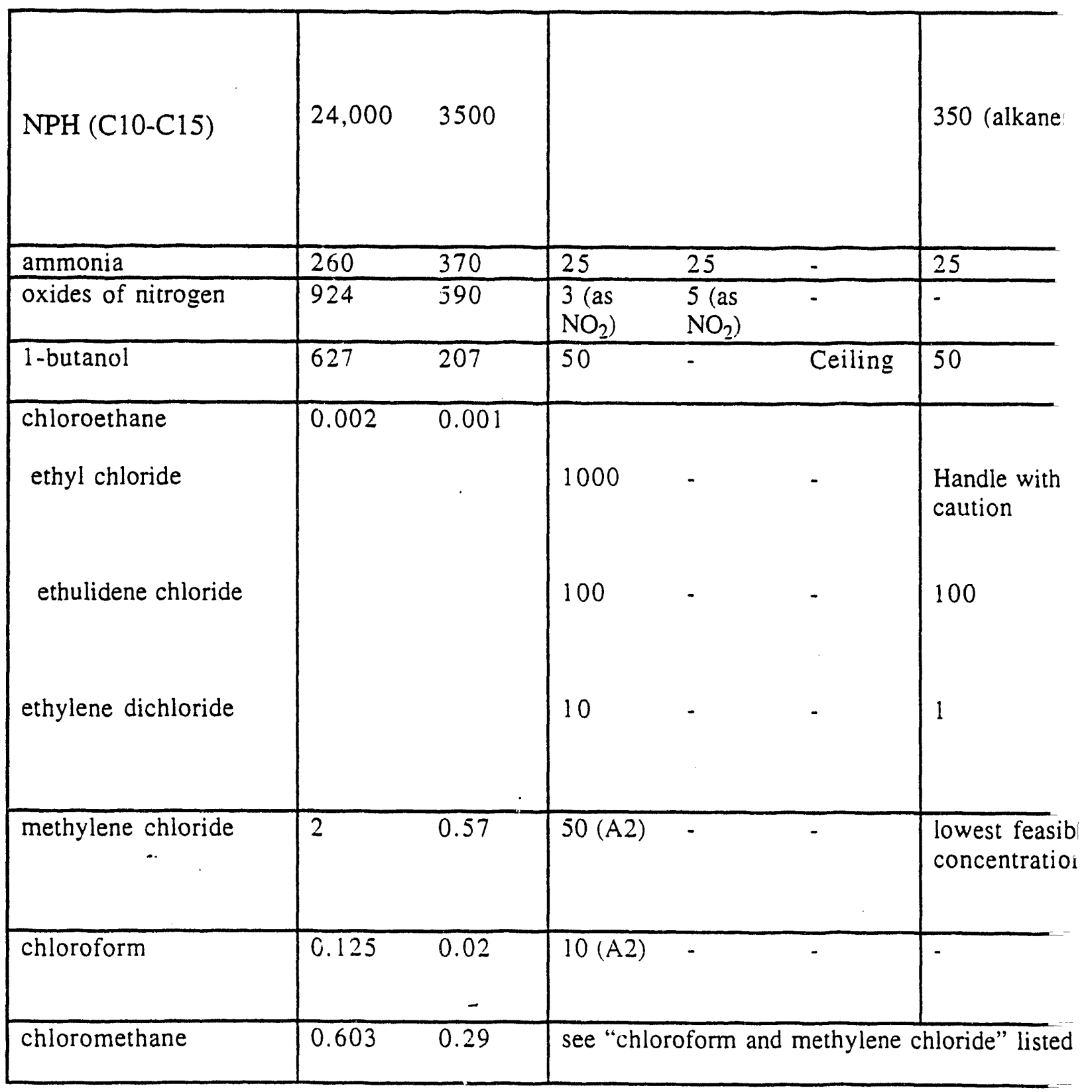




\section{Tank 241-C-103 Summary Data}

REL, ppm

Human Serv. 1992;

PEL, ppm

Sax and Lewis 1989: Health

ook 1987)

(29 CFR 1910: Cook 1987)

Human Serv. 1990: HEW 1977)

Ceiling $\quad 8-\mathrm{h} \quad$ Ceiling

STEL or Skin TWA STEL or Skin Health Effects \& Safety Hazards

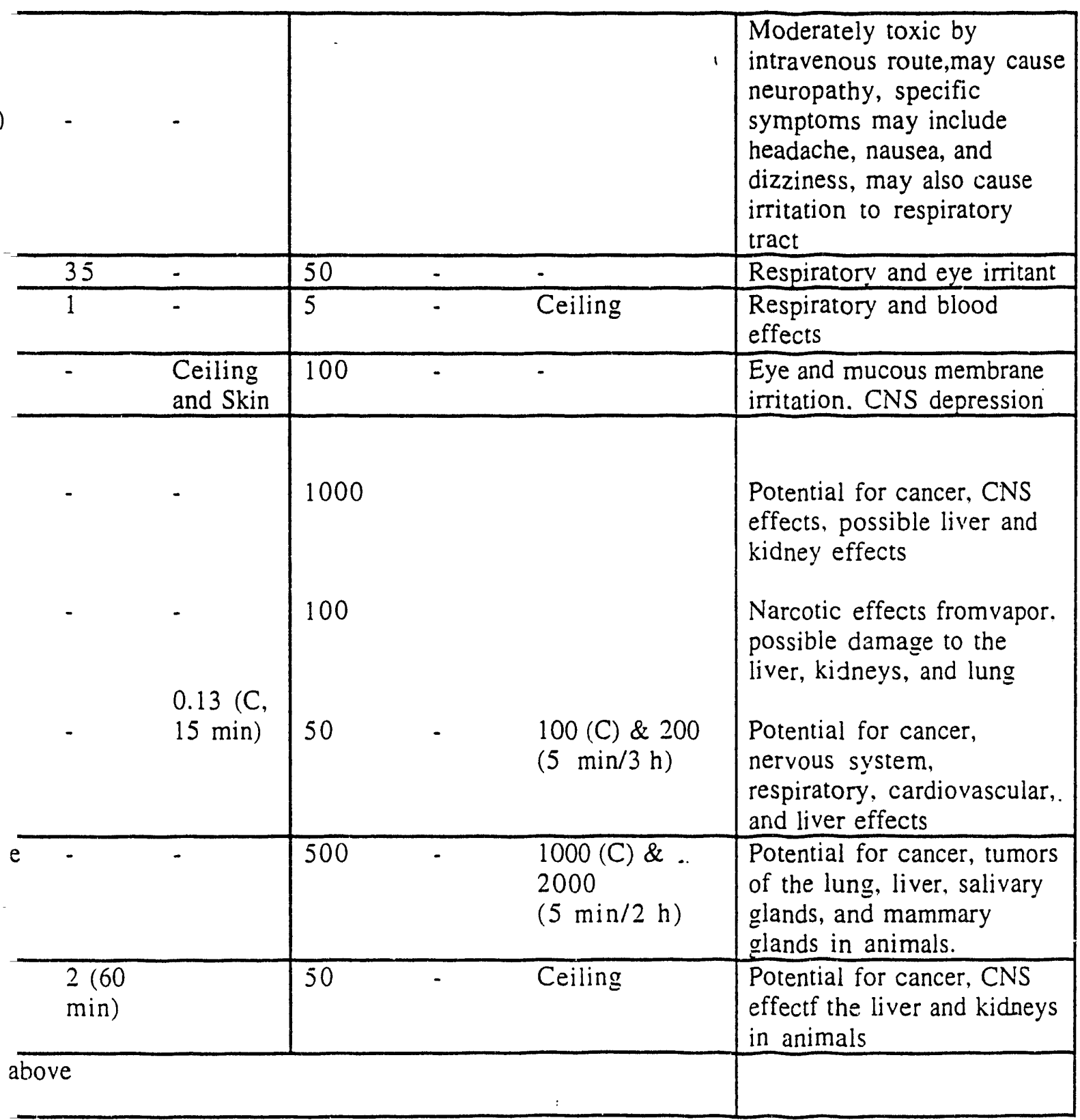


Reported

Concentration $^{(a)}$

TLV, ppm

(American Conf. 1992-93:

Cook 1987)

Selected Chemicals ${ }^{(a)} \quad \mathrm{mg} / \mathrm{m}^{3} \quad \mathrm{ppm} \quad$ TWA STEL or Skin 8-h TWA

\begin{tabular}{|c|c|c|c|c|c|c|}
\hline $\begin{array}{l}\text { dichloroethylene } \\
\text { vinylidene chloride } \\
\text { 1,2-dichloroethylene }\end{array}$ & 0.0008 & 0.0002 & $\begin{array}{l}5 \\
200\end{array}$ & $\begin{array}{l}20 \\
-\end{array}$ & $\begin{array}{l}- \\
-\end{array}$ & $\begin{array}{l}\text { lowest fe: } \\
\text { concentra } \\
200\end{array}$ \\
\hline dichloroethane & 0.029 & 0.007 & \multicolumn{4}{|c|}{ see "chloroethane" above } \\
\hline trichlorofluoromethane & 0.63 & 0.099 & & & & \\
\hline $\begin{array}{l}\text { bromoethane (ethyl } \\
\text { bromide) }\end{array}$ & 0.0019 & 0.0004 & $5(A 2)$ & - & Skin & $\cdot$ \\
\hline carbon tetrachloride & 0.106 & 0.017 & $5(\mathrm{~A} 2)$ & - & Skin & - \\
\hline bromodichloromethane & 0.0056 & 0.0008 & & & & \\
\hline $\begin{array}{l}\text { dichloroproane } \\
\text { (propylene dichloride) }\end{array}$ & 0.046 & 0.01 & 75 & 110 & - & $\begin{array}{l}\text { lowest } f_{i} \\
\text { concentri }\end{array}$ \\
\hline dichloropropene & 0.001 & 0.0003 & 1 & - & - & 1 \\
\hline
\end{tabular}


ix A: (contd)

REL, ppm

h. Human Serv. 1992;

PEL, ppm

Sax and Lewis 1989: Health

Cook 1987)

(29 CFR 1910: Cook 1987)

Human Serv. 1990: HEW 1977)

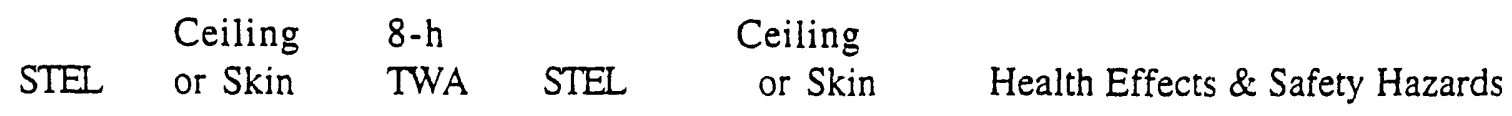

\begin{tabular}{|c|c|c|c|c|c|c|}
\hline $\begin{array}{l}\text { sible } \\
\text { tion }\end{array}$ & - & - & $\begin{array}{l}- \\
-\end{array}$ & 200 & - & $\begin{array}{l}\text { Potential for cancer, liver and } \\
\text { kidney tumors in animals } \\
\text { Narcotic effects, mucous } \\
\text { membrane irriation }\end{array}$ \\
\hline & & & & & & \\
\hline & - & - & 200 & 250 & - & $\begin{array}{l}\text { Skin irritation, ACGIH has } \\
\text { listed this compound as a } \\
\text { suspected human carcinogen }\end{array}$ \\
\hline & $\begin{array}{l}2(60 \\
\min ) \\
\end{array}$ & Ceiling & 10 & & $\begin{array}{l}25(\mathrm{C}) \& 200 \\
(5 \mathrm{~min} / 4 \mathrm{~h}) \\
\end{array}$ & Liver cancer \\
\hline $\begin{array}{l}\text { sible } \\
\text { tion }\end{array}$ & - & - & 75 & $\overline{-}$ & - & $\begin{array}{l}\text { Potential for cancer, narcosi } \\
\text { eye irritation, mammary gland } \\
\text { tumors and liver tumors in } \\
\text { animals }\end{array}$ \\
\hline & - & Skin & - & - & - & $\begin{array}{l}\text { Potential for cancern, cancer } \\
\text { adder, lung, and forestomach in } \\
\text { animals }\end{array}$ \\
\hline
\end{tabular}


TLV, ppm

Reported

Concentration ${ }^{(a)}$

(American Conf. 1992-93:

Cook 1987)

\begin{tabular}{|c|c|c|c|c|c|}
\hline Selected Chemicals ${ }^{(a)}$ & $\mathrm{mg} / \mathrm{m}^{3}$ & $\mathrm{ppm}$ & $\begin{array}{l}8-h \\
\text { TWA }\end{array}$ & STEL & $\begin{array}{l}\text { Ceiling } \\
\text { or Skin }\end{array}$ \\
\hline dichlorobromo-methane & 0.0004 & 0 & & & \\
\hline $\begin{array}{l}\text { trichloroethane } \\
\text { methyl chlorororm }\end{array}$ & 0.0414 & 0.007 & 350 & 450 & 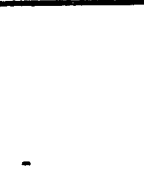 \\
\hline 1,1,2-trichloroethane & & & 10 & - & Skin \\
\hline tetrachloroethylene & 0.096 & 0.0006 & $25(\mathrm{~A} 3)$ & $100(\mathrm{~A} 3)$ & - \\
\hline $\begin{array}{l}\text { tetrachloroethane } \\
\text { 1,1,1,2- } \\
\text { tetrachloroethane } \\
\text { 1.2-dichloroethylene }\end{array}$ & 0.058 & 0.014 & $\begin{array}{l}- \\
1\end{array}$ & $\begin{array}{l}- \\
-\end{array}$ & Skin \\
\hline trichloroethy'lene & 0.004 & 0.0007 & $50(A 5)$ & $100(\mathrm{~A} 5)$ & - \\
\hline tributyl phosphate & 221 & 20 & 0.2 & - & - \\
\hline acetone & 5440 & 2290 & 750 & 1000 & - \\
\hline 2-butanone (MEK) & $\begin{array}{r}39 \\
-\quad \\
\end{array}$ & 13.2 & 200 & 300 & - \\
\hline 2-hexanone (MnBK) & 6.3 & 1.5 & $\overline{5}$ & - & Skin \\
\hline
\end{tabular}


sppendix A: (contd)

REL, ppm

(Health. Human Serv. 1992;

Cook 1987)

PEL, ppm

(29 CFR 1910: Cook 1987)

(Sax and Lewis 1989; Health

Human Serv. 1990: HEW 1977)

\begin{tabular}{|c|c|c|c|c|c|c|}
\hline & & $\begin{array}{l}\text { Ceiling } \\
\text { or Skin }\end{array}$ & $\begin{array}{l}8-\mathrm{h} \\
\text { TWA }\end{array}$ & STEL & $\begin{array}{l}\text { Ceiling } \\
\text { or Skin }\end{array}$ & Health Effects \& Safety Hazards \\
\hline
\end{tabular}

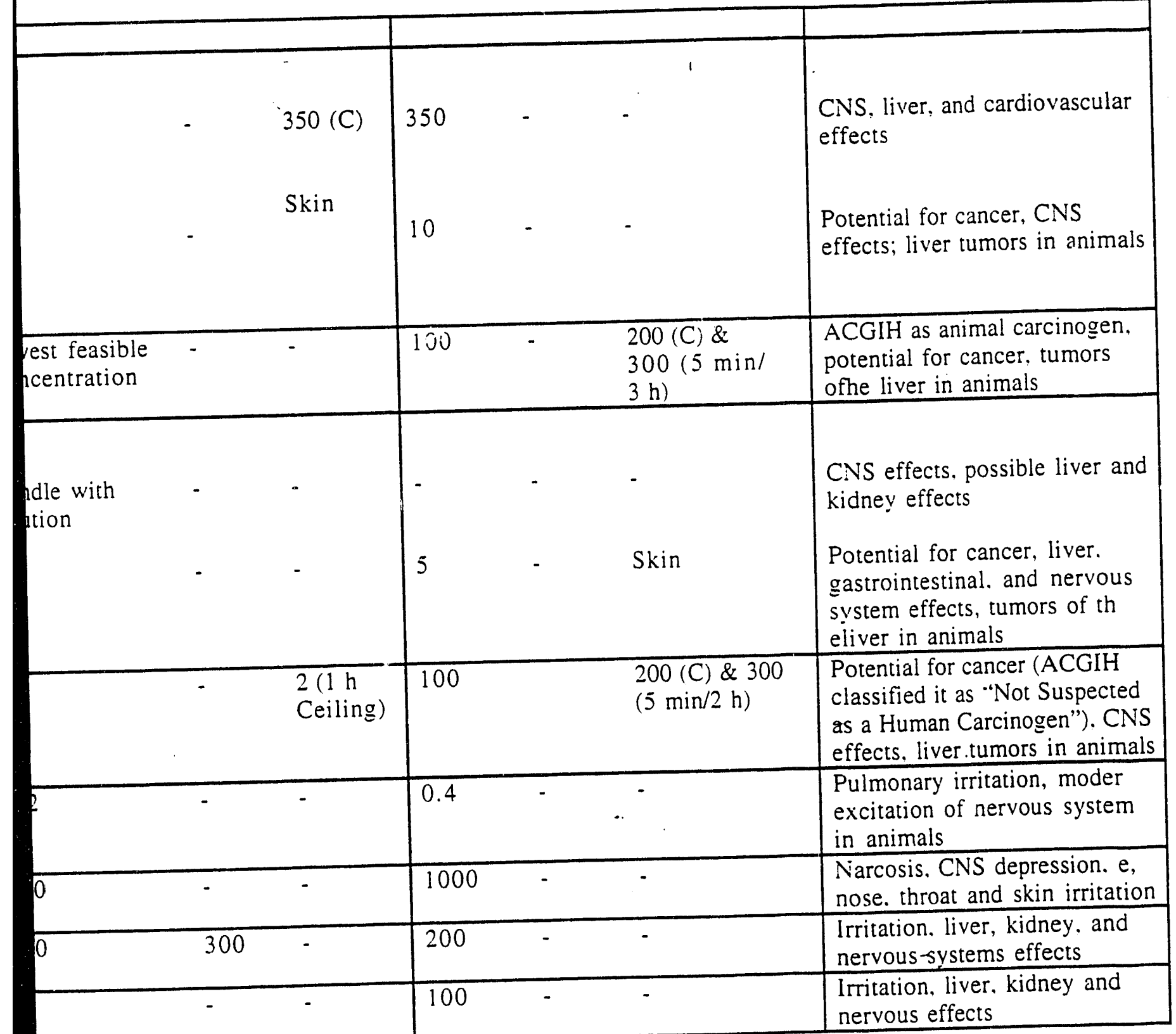


TLV, ppm

Reported

Concentration ${ }^{\text {(a) }}$

(American Conf. 1992-93:

(H)

Cook 1987)

\begin{tabular}{|c|c|c|c|c|c|c|}
\hline Selected Chemicals ${ }^{(a)}$ & $\mathrm{mg} / \mathrm{m}^{3}$ & $\mathrm{ppm}$ & $\begin{array}{l}\text { 8-h } \\
\text { TWA }\end{array}$ & STEL & $\begin{array}{l}\text { Ceiling } \\
\text { or Skin }\end{array}$ & 8-h T \\
\hline $\begin{array}{l}\text { 4-methyl 2-pentanone } \\
\text { (MPK) }\end{array}$ & 2.2 & 0.6 & 200 & 250 & - & 150 \\
\hline vinyl chloride & 0.0079 & 0.003 & $5(\mathrm{~A} 1)$ & - & - & $\begin{array}{l}\text { lowest } \\
\text { conce }\end{array}$ \\
\hline vinyl acetate & 1.9 & 0.54 & 10 & 20 & - & - \\
\hline benzene & 0.65 & 0.2 & $\begin{array}{l}10(\mathrm{~A} 2) \\
(0.1)\end{array}$ & - & - & 0.1 \\
\hline toluene & 0.474 & 0.13 & 50 & - & Skin & 100 \\
\hline chlorobenzene & 0.021 & 0.004 & 10 & - & - & - \\
\hline styrene & 0.048 & 0.011 & 50 & 100 & Skin & 50 \\
\hline ehtylbenzene & 0.0104 & 0.002 & 100 & 125 & - & $\overline{100}$ \\
\hline 0 -xylene & 9.3 & 2.14 & 100 & 150 & - & $\overline{100}$ \\
\hline carbon disulfide & 0.118 & 0.038 & 10 & - & Skin & 1 \\
\hline hydrogen sulfide & 16 & 11.5 & 10 & 15 & - & - \\
\hline hydrogen cyanide & $<0.14$ & -0.13 & 10 & - & $\begin{array}{l}\text { Ceiling } \\
\& \text { Skin }\end{array}$ & - \\
\hline sulfur dioxide & 0.156 & -6.1 & 2 & 5 & - & 2 \\
\hline
\end{tabular}


Appendix A: (contd)

REL, ppm

alth. Human Serv. 1992:

PEL, ppm

29 CFR 1910: Cook 1987)

(Sax and Lewis 1989: Health

Cook 1987)

8-h Ceiling

${ }^{T} A$ STEL or Skin TWA STEL or Skin

Human Serv. 1990: HEW 1977)

Health Effects \& Safety Hazards

\begin{tabular}{|c|c|c|c|c|c|c|}
\hline & - & $\cdot$ & 200 & - & - & $\begin{array}{l}\text { Irritation. liver. kidney, and } \\
\text { nervous sistem effects }\end{array}$ \\
\hline \multirow[t]{4}{*}{$\begin{array}{l}\text { feasible } \\
\text { ration }\end{array}$} & - & - & 1 & - & 5 (Ceiling) & $\begin{array}{l}\text { Liver cancer (ACGIH } \\
\text { "Confirmed Human } \\
\text { Carcinogen") }\end{array}$ \\
\hline & - & $\begin{array}{l}4(15 \mathrm{~min} \\
\text { Ceiling })\end{array}$ & - & - & $\cdot$ & Eve, nose. and throat irritation \\
\hline & - & $\begin{array}{l}1(15 \mathrm{~min} \\
\text { Ceiling) }\end{array}$ & 10 & - & $\begin{array}{l}25(\mathrm{C}) \& 50 \\
(10 \mathrm{~min})\end{array}$ & Cancer (leukemia) \\
\hline & 150 & - & 200 & & $\begin{array}{l}300(\mathrm{C}) \& 500 \\
(10 \mathrm{~min} / 8 \mathrm{~h})\end{array}$ & CNS depression \\
\hline & - & - & 75 & - & - & $\begin{array}{l}\text { Irritant to skin. eye, and } \\
\text { mucous membrane of upper } \\
\text { respiratory tract, acute } \\
\text { exposure may olead to CNS } \\
\text { effects, liver. kidney and lung } \\
\text { damage in animals }\end{array}$ \\
\hline & 100 & - & 100 & - & $\begin{array}{l}200(\mathrm{C}) \& 400 \\
(5 \mathrm{~min} / 3 \mathrm{~h})\end{array}$ & $\begin{array}{l}\text { Nervous system effects. eye } \\
\text { and respiratory irritation. } \\
\text { reproductive effects }\end{array}$ \\
\hline & 125 & - & 100 & - & - & $\begin{array}{l}\text { Eye. skin. and upper } \\
\text { respiratory and eve irritation }\end{array}$ \\
\hline & 150 & - & 100 & $\cdot$ & - & $\begin{array}{l}\text { CNS depression. respiratory } \\
\text { and eve irritation }\end{array}$ \\
\hline & 10 & Skin & 20 & - & $\begin{array}{l}30(\mathrm{C}) \& 100 \\
(30 \mathrm{~min})\end{array}$ & $\begin{array}{l}\text { Cardiovascular. } \mathrm{CNS} \text {, and } \\
\text { repdocutive effects }\end{array}$ \\
\hline & - & $\begin{array}{l}10(10 \mathrm{~min} \\
\text { Ceiling) }\end{array}$ & - & & $\begin{array}{l}20(\mathrm{C}) \& 50 \\
(10 \text { min once })\end{array}$ & $\begin{array}{l}\text { Irritation and severe acute } \\
\text { effects on nervous and } \\
\text { respiratory systems }\end{array}$ \\
\hline & 4.7 & Skin & 10 & - & Skin & $\begin{array}{l}\text { Thyroid, blood, and } \\
\text { respiratory effects }\end{array}$ \\
\hline & 5 & - & 5 & - & - & Respiratory effects \\
\hline
\end{tabular}


TLV, ppm

Reported

Concentration $^{(a)}$
(American Conf. 1992-93:

Cook 1987)

REL, ppmi Health, Human S

Cook 1987

\begin{tabular}{|c|c|c|c|c|c|c|}
\hline Selected Chemicals(a) & $\mathrm{mo} / \mathrm{m}^{3}$ & nom & $\begin{array}{l}8-h \\
\text { TWA }\end{array}$ & STEL & $\begin{array}{l}\text { Ceiling } \\
\text { or Skin }\end{array}$ & 8-h TWA \\
\hline
\end{tabular}

\begin{tabular}{|c|c|c|c|c|c|c|c|}
\hline sulfur trioxide & 16 & -4.9 & & & & - & - \\
\hline hydrogen fluoride & $<50$ & 73.3 & 3 & & Ceiling & 3 & 6 \\
\hline methylamine & & -5 to 10 & 5 & 15 & - & 10 & $\cdot$ \\
\hline acetonitrile & 0.2 & 0.12 & 40 & 60 & - & 20 & - \\
\hline hydrogen & $<1.2$ & 1.47 & - & - & - & - & - \\
\hline acetic acid & 1.3 & $\sim 0.5$ & 10 & 15 & - & 10 & 15 \\
\hline
\end{tabular}

(a)Internal memo from Wnstinghouse Hanford Company, March 5, 1992. Subject: Tank 241-C-103

\section{References}

29 CFR 1910. 1993. Subpart Z, "Toxic and Hazardous Substances," U.S. Code of Federal Regula American Conference of Governmental Industrial Hygienists, Inc. 1992-1993. Threshold Limit Val Cook, W. A. 1987. Occupational Exposure Limits - Worldwide. American Industrial Hygiene Ass Sax, N. I., and R. J. Lewis. 1989. Dangerous Properties of Industrial Materials. Vol. I-III. 7th E U.S. Department of Health and Human Services. 1990. Pocket Guide to Chemical Hazards. DHF U.S. Department of Health and Human Services. 1992. NIOSH Reconmendations for Occupation. Cincinnati.

U.S. Department of Health, Education, and Welfare. 1977. Occupational Diseases - A Guide to .Tl 
Appendix A: (contd)

$\begin{array}{ll}\text { PE. 1992: } & \text { (Sax and Lewis 1989: Health } \\ \text { (29 CFR 1910: Cook 1987) } & \text { Human Serv. 1990: HEW 1977) }\end{array}$
Ceiling
$8-h$
Ceiling
or Skin
TWA STEL or Skin
Health Effects \& Safety Hazards

\begin{tabular}{l|lll|l|}
\hline- & - & - & - & $?$ \\
\hline- & 3 & - & - & $\begin{array}{l}\text { Skin, eye, and airway } \\
\text { irritation. bone effects }\end{array}$ \\
\hline- & 10 & - & - & $\begin{array}{l}\text { Severe eye and respiratory } \\
\text { irritation }\end{array}$ \\
\hline- & 40 & - & - & $\begin{array}{l}\text { Eye, nose, and throat irritation } \\
\text { from vapor, skin and eye } \\
\text { irritation from liquid, nervous } \\
\text { system effects }\end{array}$ \\
\hline- & - & - & - & Simple asphyxiant \\
\hline- & 10 & - & - & $\begin{array}{l}\text { Skin, eye, and mucous } \\
\text { membrane irritation }\end{array}$ \\
\hline
\end{tabular}

Vapor Constituents.

ions.

Ies for Chemical Substances and Physical Agents and Biological Exposure Indices, Cincinnati.

sciation, Fairfax, Virginia.

dition. Van Nostrand Reinhold Company, New York.

S (NIOSH) Publication No. 90-117. Ci.ıcinnati.

I Safety and Health, Compendium of Policy Documents and Statements. DHHS (NIOSH) Publication No. 92-100.

eir Recognition. Revised Edition. DHEW (NIOSH) Publication No. 77-181, Cincinnati. 
Appendix B

Evaluation of Sandia/Oregon Graduate Institute Report on Vapors from Tank 241-C-103 


\section{Appendix B. Preliminary Evaluation}

Vapor Concistration Hawkins (-1 ill. 19911 $B(\bullet, 1$
$\mathrm{TLV}, \mathrm{mg} / \mathrm{m}^{3}$

$95 \%$

(Hawkins et al. 1991)
(American Conf. 1992-93;

Cook 1987)

Estimialc of

Selected Chemicals GM Trut Mcian (Einfeld et al. 1992) $\mathrm{mg} / \mathrm{m}^{3} \mathrm{mg} / \mathrm{ml}^{3}$ $\begin{array}{ccccc}\mathrm{LCL} & \mathrm{UCL} & \mathrm{UTL}, & \delta-\mathrm{h} \\ \mathrm{mg} / \mathrm{m}^{3} & \mathrm{mg} / \mathrm{m}^{3} & \mathrm{mg} / \mathrm{m}^{3} & \text { TWA }\end{array}$ Ceiling STEL or Skin

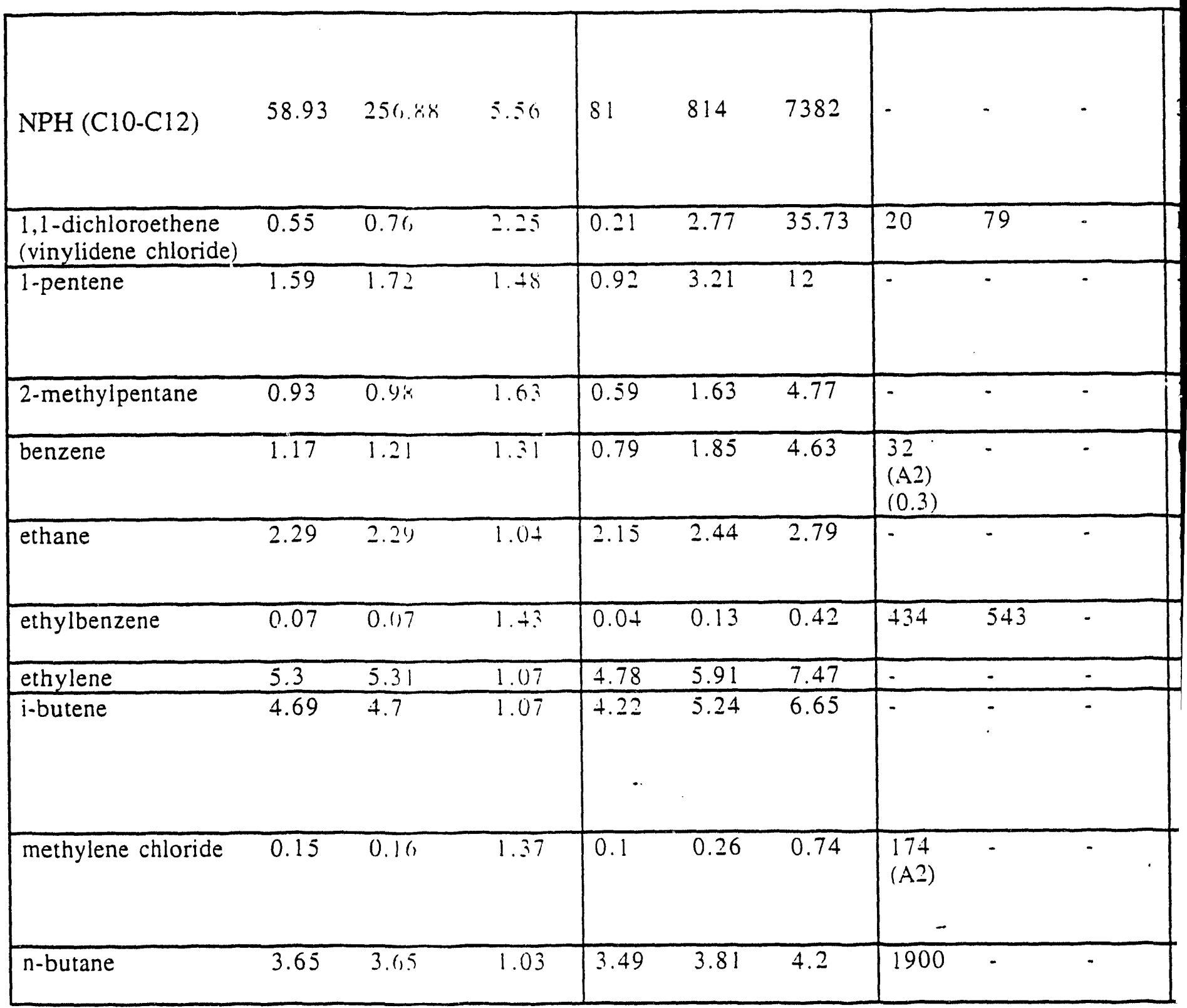




\section{f Sandia/OGIST Report Dated September 22, 1992}

$\mathrm{REL}, \mathrm{mg} / \mathrm{m}^{3}$

(Health, Human Serv. 1992: Cook 1987)
PEL, $\mathrm{mg} / \mathrm{m}^{3}$

(29 CFR 1910;

Cook 1987)
(Sax and Lewis 1989; Health Human Serv. 1990: HEW 1977)

\section{Ceiling 8-h Ceiling \\ 8-h TWA STEL or Skin TWA STEL or Skin \\ Health Effects \& Safety Hazards}

\begin{tabular}{|c|c|c|c|c|c|c|}
\hline $5(j$ (alkanes) & - & - & - & - & $\checkmark$ & $\begin{array}{l}\text { Moderately toxic by } \\
\text { intravenous route, may cause } \\
\text { neuropathy, specific } \\
\text { symptoms may include } \\
\text { headache, nausea. and } \\
\text { dizzi.zess, may also cause } \\
\text { irritation to respiratory tract }\end{array}$ \\
\hline \multirow[t]{2}{*}{ owest feasible } & - & - & $\cdot$ & $\cdot$ & $\cdot$ & $\begin{array}{l}\text { Potential for concern, liver and } \\
\text { kidnev tumors in animals }\end{array}$ \\
\hline & - & - & - & - & - & $\begin{array}{l}\text { Fire ind explosion hazard, } \\
\text { reactive to oxidizer. } \\
\text { decompose to acrid smoke and } \\
\text { irritating fumes }\end{array}$ \\
\hline 350 (alkanes) & - & - & - & - & $\cdot$ & $\begin{array}{l}\text { Eye irritant. may cause } \\
\text { narcotic effects }\end{array}$ \\
\hline$\longdiv { . 3 2 }$ & - & $3.2(15 \mathrm{~min})$ & 32 & - & $\begin{array}{l}80(\mathrm{C}) \& 160 \\
(10 \mathrm{~min})\end{array}$ & Cancer (leukemia) \\
\hline 350 (alkanes) & - & $\overline{-}$ & & & & $\begin{array}{l}\text { Moderately toxic by } \\
\text { intravenous route. may cause } \\
\text { neuropathy }\end{array}$ \\
\hline 435 & 545 & $\cdot$ & - & 435 & $\cdot$ & $\begin{array}{l}\text { Eye. skin, and upper repiratory } \\
\text { irritation }\end{array}$ \\
\hline & - & - & - & - & - & Simple asphyxiant \\
\hline - & 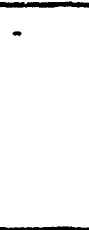 & - & - & $\overline{-}$ & - & $\begin{array}{l}\text { Simple asphyxiant,may cause } \\
\text { narctoic action, fire and } \\
\text { explosion hjazard, decompose } \\
\text { to acrid smoke and irritating } \\
\text { fumes }\end{array}$ \\
\hline $\begin{array}{l}\text { lowest feasible } \\
\text { concentration }\end{array}$ & - & - & 1737 & - & $\begin{array}{l}3474(\mathrm{C}) * 6947 \\
(5 \mathrm{~min} / 2 \mathrm{~h})\end{array}$ & $\begin{array}{l}\text { Potential for cancer, tumors of } \\
\text { the lung, liver. salivary } \\
\text { glands, and mammary glands } \\
\text { in animals }\end{array}$ \\
\hline 900 & - & - & - & - & - & $\begin{array}{l}\text { Drowsiness and other narcotic } \\
\text { effects }\end{array}$ \\
\hline
\end{tabular}


Vapor Concentration (Hawkins et al. 1991) Best

Estimate of

Selected Chemicals GM True Mean (Einfeld et al. 1992) $\mathrm{mg} / \mathrm{m}^{3} \mathrm{mg} / \mathrm{m}^{3}$
$95 \%$

(Hawkins et al. 1991)
TLV, mg.' $\mathrm{m}^{3}$

(American Conf. 1992-93;

Cook 1987)

\begin{tabular}{|c|c|c|c|c|c|c|c|c|c|}
\hline n-decane & 9.23 & 7.87 & 7.87 & 7.87 & 10.98 & 15.73 & - & - & - \\
\hline$n$-hexane & 3.03 & 3.04 & 1.08 & 2.7 & 3.42 & 4.44 & 176 & - & - \\
\hline n-octane & 3.01 & 3.03 & 1.11 & 2.55 & 3.59 & 5.23 & 1400 & 1750 & - \\
\hline n-pentane & 3.25 & 3.38 & 1.32 & 2.16 & 5.29 & 13.81 & 1770 & 2210 & - \\
\hline propane & 3.18 & 3.18 & 1.03 & 3.05 & 3.32 & 3.65 & - & - & - \\
\hline propene & 5.72 & 5.78 & 1.16 & 4.59 & 7.28 & 12.08 & - & - & - \\
\hline sytrene & 0.03 & 0.09 & 4.32 & 0.009 & 0.92 & 57.48 & 213 & 426 & Skin \\
\hline toluene & 0.69 & 0.73 & 1.39 & 0.43 & 1.23 & 3.75 & 188 & - & Skin \\
\hline undecane & 69.95 & 72.66 & 1.32 & 46.87 & 112.6 & 288.78 & - & - & \\
\hline xylene & 0.18 & 0.28 & 2.49 & 0.12 & 0.63 & 3.36 & 434 & 651 & - \\
\hline total non-CH4HCs & 2179 & 2474.19 & 1.66 & 1110 & 5517 & 29138 & - & - & - \\
\hline
\end{tabular}

(a) W. Einfeld, R. A. Rasmussen, and L. D. Bustard. 1992. Interim Report - Hanford Tank 103C Heads] Institute of Science and Technology.

LCL, UCL UTL, $8-\mathrm{h}$ GSD $\mathrm{mg} / \mathrm{m}^{3} \quad \mathrm{mg} / \mathrm{m}^{3} \quad \mathrm{mg} / \mathrm{m}^{3} \quad$ TWA
Ceiling STEL or Skin 
!ndix B. (contd)

REL. $\mathrm{mg} / \mathrm{m}^{3}$

(Health, Human Serv.

1992: Cook 1987)
PEL. $\mathrm{mg} / \mathrm{m}^{3}$

(29 CFR 1910;

Cook 1987)
(Sax and Lewis 1989; Health

Human Serv. 1990: HEW 1977)

Ceiling 8-h Ceiling

8-h TWA STEL or Skin TWA STEL or Skin Health Effects \& Safety Hazards

\begin{tabular}{|c|c|c|c|c|c|c|}
\hline 50 (alkanes) & $\cdot$ & - & $\cdot$ & - & -1 & $\begin{array}{l}\text { Moderately toxic by } \\
\text { intravenous route, may cause } \\
\text { neuropathy }\end{array}$ \\
\hline 80 & - & - & - & - & $\cdot$ & $\begin{array}{l}\text { Skin and nervous system } \\
\text { effects }\end{array}$ \\
\hline 50 & - & $1800(15 \mathrm{~min})$ & 2350 & - & - & $\begin{array}{l}\text { Skin and nervous system } \\
\text { effects }\end{array}$ \\
\hline 50 & - & $1800(15 \mathrm{~min})$ & 2950 & - & - & $\begin{array}{l}\text { Skin and nervous system } \\
\text { effects }\end{array}$ \\
\hline \multirow[t]{2}{*}{800} & - & - & 1800 & - & - & Simple asphyxiant \\
\hline & - & $\overline{-}$ & - & - & - & $\begin{array}{l}\text { Simple asphyxiant, } \\
\text { compressed liquid can cause } \\
\text { skin burns from freezing } \\
\text { effects on tissue of rapid } \\
\text { evaporation }\end{array}$ \\
\hline 15 & 425 & - & 426 & - & $\begin{array}{l}852(C) \& 2556 \\
(5 \mathrm{~min} / 3 \mathrm{~h})\end{array}$ & $\begin{array}{l}\text { Nervous system effects, eye } \\
\text { and respiratory irritation. } \\
\text { reproductive effects }\end{array}$ \\
\hline 375 & 560 & - & 752 & - & $\begin{array}{l}1128(\mathrm{C}) \& 1880 \\
(10 \mathrm{~min} / 8 \mathrm{~h})\end{array}$ & CNS depression \\
\hline 350 (alkanes) & - & - & & - & - & $\begin{array}{l}\text { Moderately toxic by } \\
\text { intravenous route, may cause } \\
\text { neuropathy }\end{array}$ \\
\hline 435 & 655 & - & 435 & - & - & $\begin{array}{l}\text { CNS depression, respiratory } \\
\text { and eve irritation }\end{array}$ \\
\hline & - & - & - & - & - & $?$ \\
\hline
\end{tabular}

ace Vapor Analysis Canister Sampling Results, Sandia National Laboratories and Oregon Graduate 


\section{For Further Information}

29 CFR 1910. 1993. Subpart Z, "Toxic and Hazardous Substances." U.S. Code of Federal Regulations. American Conference of Governmental Industrial Hygienists, Inc. 1992-1993. Threshold Limit Values fo Cook, W. A. 1987. Occupational Exposure Limits - Worldwide. American Industrial Hygiene Associati Hawkins, N. E., S. K. Norwood, and J. C. Rock (eds.). 1991. A Strategy for Occupational Exposure As. Sax, N. I., and R. J. Lewis. 1989. Dangerous Properties of Industrial Materials. Vol. I-III. 7th Edition U.S. Department of Health and Human Services (HHS). 1990. Pocket Guide to Chemical Hazards. DI

U.S. Department of Health and Human Services (HHS). 1992. NIOSH Recommendations for Occupatio No. 92-100. Cincinnati.

U.S. Department of Healt'l, Education, and Welfare (HEW). 1977. Occupational Diseases - A Guide to 
ndix B. (contd)

Chemical Substances and Physical Agents and Biological Exposure Indices, Cincinnati.

in, Fairfax, Virginia.

essment. American Industrial Hygiene Association. Fairfax. Virginia.

. Van Nostrand Reinhold Company. New York.

HS (NIOSH) Publication No. 90-117. Cincinnati.

ial Safery and Health, Compendium of Policy Documents and Statements. DHHS (NIOSH) Publication

Their Recognition. Revised Edition. DHEW (NIOSH) Publication No. 77-181, Cincinnati. 


\section{Distribution}

No. of

Copies

Ofisite

12 DOE/Office of Scientific and Technical Information

Onsite

DOE Richland Operations Office

R. F. Christensen, R3-72

9 Westinghouse Hanford Company

H. Babad, R2-78

R. B. Conrad, H5-09

C. Defigh-Price, R2-31

G. T. Dukelow, R2-78

J. C. Fulton, R2-31

K. A. Gasper, R2-08

J. L. Huckaby, R2-78

G. D. Johnson, R2-78

J. W. Osborne, R2-78

MacTech

S. T. Murff, R3-82

NISI

M. S. Story, H5-09
No. of

Copies

Onsite (contd)

56 Pacific Northwest Laboratory

K. J. Allwine, K6-11

R. M. Bean, P8-08

A. L. Brooks, P7-53

T.R.W. Clauss, P8-08

J. A. Dill, K4-16

J. S. Fruchter, K6-96

S. C. Goheen, P8-08 (10)

R. J. Hall, K8-28

M. F. Jarvis, K3-54

B. M. Johnson, K1-78

B. D. Lerner, P8-08

M. W. Ligotke, P7-59

R. B. Lucke, P8-08

D. D. Mahlum, P7-56

H. S. Miley, P8-08

D. A. Nelson, P8-38

V. P. Ostrander, K7-73

K. H. Pool, P8-44

R. K. Quinn, K1-73

R. A. Renne, K4-10.

G. F. Schieffelbein, P8-38

P. R. Seesing, B1-34

M. R. Sikov, 57-53

D. L. Springer, P7-56

B. D. Thrall, P7-56

D. A. Turner, R2-78

J. Y. Young, K4-16 (15)

Publishing Coordination

Technical Report Files (5)

Distr.1 

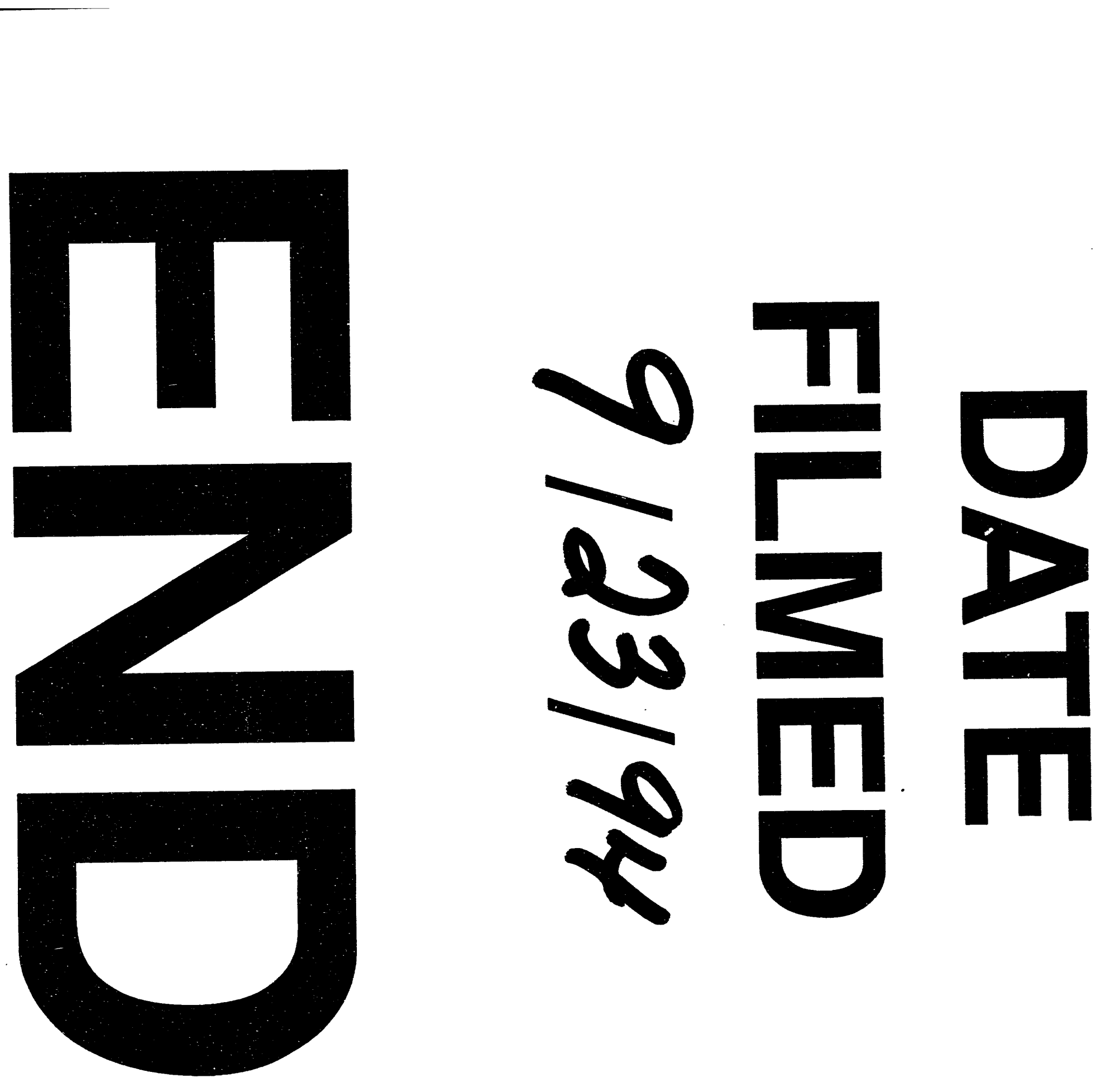
